\title{
VYJÁDŘENÍ K ROZHOVORU RADIMA UZLA ZE DNE 8. 12. 2020
}

\author{
Kateřina Bartošová, Jana Cíglerová, Hynek Cígler
}

Dne 8. 12. 2020 byl na DVTV odvysílán rozhovor s Radimem Uzlem¹ . Protože v rozhovoru zaznívají informace a názory, které jsou $\mathrm{v}$ rozporu nejen $\mathrm{s}$ aktuálními psychologickými poznatky, ale i s etickými normami a obyčejným slušným chováním, považujeme za nezbytné se k němu vyjádřit.

Tematicky rozhovor rozdělujeme do pěti částí.

\section{Co je a co není sexuální obtěžování}

Hned v prvních minutách rozhovoru uvádí Radim Uzel, že exhibicionismus není sexuální obtěžování, zatímco přinesení kávy od „potetované číšnice“, která mu je nepř́ijemná, obtěžování je. O několik minut později říká, že exhibicionismus obtěžováním být může. Současně také staví na stejnou úroveň přinesení kávy od číšnice s tetováním, jejíž vzhled mu není př́ijemný, a sprosté pokřikování na 14letou dívku na ulici kvůli jejímu poprsí. Doslova ř́ká: „Já si myslím, že to je podobný.“

Sexuální obtěžování bývá obecně definováno jako nevítané, nevhodné a urážlivé chování se sexuálním podtextem, které jedinec vnímá jako nežádoucí. V rozhovoru je na stejnou úroveň stavěna duševní porucha (exhibicionismus), tělesný vzhled člověka (potetovaná číšnice) a sprosté pokřrikování narážek se sexuální tématikou na 14letou dívku.

Jedná se tedy o zcela nesrovnatelné kategorie. Pokud Radim Uzel považuje za obtěžování to, že se „musí nechat“ obsluhovat potetovanou číšnicí, kde je pak podle něj vlastně hranice? Není obtěžováním i to, že jej bude obsluhovat člověk s nadváhou? Nebo černoch? Homosexuál? Žena? Nebo naopak muž, protože se chce raději dívat na ženu? Radim Uzel na jednu stranu kritizuje, že se dnes za sexuální obtěžování považuje kde co, na druhou stranu sám termín rozvolňuje. To vše nehledě na to, že jej nikdo nenutí nechat se obsluhovat číšnicí s tetováním a že si může podnik svobodně zvolit, na rozdíl od zmíněné dívky, která se nemůže rozhodnout pokřikování neslyšet.

Za alarmující lze pak považovat výrok, ve kterém Radim Uzel tvrdí, že se sprostým pokřikováním na nezletilé dívky je „nutné se smiŕit“. Tento výrok prímo přispívá ke kultuře násilí páchaného na ženách a je zcela nepřijatelný. S čím vším je pak nutné se smířit? Neměly by se ženy smířit i s poplácáním po zadku? Nebo nechtěnými polibky?

\footnotetext{
${ }^{1}$ DVTV: Uzel: Chlap je od přírody zviŕre, ženy by s tím měly počítat a zařídit se podle toho.

Aktuálně.cz
} 


\section{Do jaké míry je př́ípustný fyzický kontakt mezi nadř́zeným a podř́zeným}

Dalším bodem v diskuzi se stává otázka, zda je, či není vhodné „poplácat po zadku“ podřízenou kolegyni. Radim Uzel říká, že „plácání po zadku kolegyně nepatří v některých případech do sexuálního obtěžování“, „vede to k proteplení vztahư“ a „nevadí, když nadřízený plácne podřízenou po zadku“.

„Poplácání po zadku“ je gestem se zjevným sexuálním podtónem. Obecně platí, že na těla cizích lidí většinou bez vyzvání nebo souhlasu dotyčného nesaháme. Na lidském těle je navíc několik intimních oblastí, na které cizím lidem bez souhlasu nesaháme nikdy (prsa, zadek, genitálie).

Zákon o zaměstnanosti doslova říká: „Sexuálním obtěžováním se rozumí jakákoliv forma nežádoucího ústního nebo jiného než ústního projevu sexuální povahy, jehož cílem nebo výsledkem je narušení důstojnosti osoby, zejména když se vytváří zastrašující, nepráátelské, ponižující, pokořující nebo urážející prostředí.“

Zaměstnanec $\mathrm{v}$ podřízeném postavení může $\mathrm{v}$ podobné situaci zvažovat potenciální následky odmítnutí sexuálního kontaktu - včetně ztráty pozice či práce a finančního zabezpečení. Radim Uzel se tak vyjadřuje v prímém rozporu s tím, co stanovuje zákon, což je problematické zejména u člověka působícího jako soudní znalec v oboru sexuologie.

Na dotaz, zda toto „poplácání“ zdravotním sestrám nevadilo, odpovídá pan Uzel: „To já bych poznal." Tímto výrokem vlastně tvrdí, že je schopen zcela jasně u cizí osoby rozpoznat, co si myslí. Lidské vnímání světa je přitom ovlivňováno množstvím faktorů a bývá zkreslené našimi dlouhodobými postoji a přesvědčeními. Nikdo, ani doktor Uzel, si nemůže být zcela jistý tím, co si druhá osoba myslí, pokud ta mu to neřekne. I pokud by to doktor Uzel správně rozpoznal $\mathrm{v}$ devíti z deseti př́ípadů, domníváme se, že jeho újma - pokud si toto poplácání desetkrát odepře - bude stále menší než újma té jedné zdravotní sestry, která se neodváží si postěžovat.

\section{Souhlas se sexem}

V další části rozhovoru zaznívá velmi nebezpečný názor, že „ptát se na výslovný souhlas je špatný model sexuálního seznamování a sexuální schůzky“ a ,jestli to (sex) žena chce, musí vyplynout ze situace, já to poznám.“

Zde se vracíme k předchozímu bodu. Pokud nám druhá osoba nesdělí, co jí běží hlavou za myšlenky, nemůžeme to vědět. Dokážeme si např́íklad představit situaci, ve které muž ve vedoucí pozici poplácává opakovaně podřízené kolegyně po zadku, a protože ony se neohradily, začne sám sebe považovat za sexuálně žádaného muže. Toto přesvědčení pak ovlivní jeho vnímání situace a prosté mlčení může považovat za souhlas, přestože ze strany ženy se jedná o strach.

Jasnou odpověd’ Radim Uzel nepodává ani na otázku, zda žena může po deseti minutách sexuálního aktu říct, že se jí to nelíbí a chce přestat. Doslova říká:

„To je složitější. Když žena obviní muže ze znásilnění, protože se jí to nelíbilo, tak to není znásilnění,“ a následně dodává: „Měl by být (nesouhlas) respektován, ale i soudněznalecky je to zpochybnitelné.“

Chápeme-li tuto část rozhovoru správně, Radim Uzel si otázku vyložil ve smyslu - žena nebyla spokojena se sexem, a tedy se následně muži mstí a obviní ho ze znásilnění. I takové prŕípady se jistě mohou objevit. Zarážející je, že přestože otázka Martina Veselovského byla 
v rozhovoru položena zcela jasně - tedy, zda žena může odmítnout sex v jeho průběhu - zcela chybí pohled na situace, kdy jeden z partnerů v průběhu sexu změní názor nebo nesouhlasí s některou sexuální praktikou a odmítne ji.

Deklarace sexuálních práv ${ }^{2}$ ŕká: „Sexuální zdraví vyžaduje pozitivní a respektující př́stup k sexualitě a sexuálním vztahům, stejně jako možnost prožívat př́ijemné a bezpečné sexuální zážitky, bez donucování, diskriminace a násilí. “3 Pokud se tedy muži nebo ženě něco v průběhu sexuálního aktu nelíbí, má plné právo s danou aktivitou přestat.

Pokud muž pokračuje se sexuálním aktem i přes nesouhlas partnerky, jedná se samozřejmě o znásilnění (a naopak). Argument, že muži mají více testosteronu, a tedy nedokážou ovládat své pudy, je mylný a nepřijatelný. Ačkoli množství testosteronu a projevy agresivity spolu sice možná, avšak velmi slabě souvisí, drtivá většina mužů své chování naštěstí dokáže ovládat a jednat způsobem, který není pro ženy nepř́ijemný a ponižující; a to i v průběhu sexuálního aktu. To, že s tím má menšina mužů potíže, není argumentem, aby se jim ženy v tomto ohledu přizpůsobily, ale výzvou těmto mužům, aby se své pudy naučili zvládat, nebo aby čelili důsledkům toho, že to nedokážou. Normou v civilizované společnosti nejsou neurvalí násilníci, ale lidé kultivovaní, kteří své chování umí mít pod kontrolou.

Pro př́ipad pochybností o tom, co souhlas se sexem znamená, nabízíme krátké poučné video: https://www.youtube.com/watch?v=oQbei5JGiT8

\section{Vědecká činnost}

Radim Uzel se v rozhovoru zaštit’uje svou vědeckou prací. Na tomto místě považujeme za nezbytné zdůraznit, že vědecká aktivita Radima Uzla je sporná, což je patrné už z toho, jak zaměňuje prostou anketu s vědeckým výzkumem. Žádná $z$ jeho publikací není ve všeobecně uznávaných databázích vědeckých prací (Scopus, Web of Science, PubMed). Je autorem většího množství populárně-naučných publikací, nejde však o odborné publikace. Jejich kvalitu zde hodnotit nechceme.

\section{Může si žena ,zavinit“ znásilnění svým chováním?}

V závěru rozhovoru přechází pan Veselovský k citaci z knihy Zvíře nadržené: „Nezaviní si někdy žena znásilnění sama svou lehkomyslností?““ a Radim Uzel odpovídá: „Ano. Je tomu tak." Přidává i př́́klad ze soudně znalecké praxe, že pokud si žena pozve o půlnoci dva podnapilé muže do bytu ,... musí počítat s tím, že to nedopadne dobře.“ Přidává i posměšnou poznámku: „Co předpokládá? Že se bude recitovat poezie?“

Tento výrok opět jednoznačně přispívá ke kultuře násilí a nelze ho nechat bez povšimnutí. Znásilnění dnes zažije desetina občanů České republiky, nějakou formu sexuálního obtěžování pak více než třetina ${ }^{4} \mathrm{z}$ nich. Toto násilí se navíc týká i nezletilých osob. V takové situaci opravdu nelze veřejně polemizovat o tom, kdo a čím přispěl k tomu, že k znásilnění došlo. Sexuální výchova není pouze o tom, jak učit dívky říkat ne, ale především o tom, jak naučit

\footnotetext{
${ }^{2}$ Wayback Machine (archive.org) - verze z roku 2014

3 "Sexual health requires a positive and respectful approach to sexuality and sexual relationships, as well as the possibility of having pleasurable and safe sexual experiences, free of coercion, discrimination and violence."

${ }^{4}$ Persefona. (2016, 5.10.). Sexuální násilí nebo obtěžování zažilo 39 \% Čechů [tisková zpráva].
} 
muže, co je a co není přijatelné chování. Takže představa dvou podnapilých mužů, jak v noci ženě recitují poezii, by měla být $\mathrm{v}$ tomto ohledu daleko přijatelnější a normálnější než představa, jak ji proti její vůli znásilňují.

Pokud bychom uvažovali podobným způsobem jako Radim Uzel, dostaneme se k tomu, co dělá většina obětí násilného činu - tedy k hledání „kde jsem udělala chybu, co jsem měla udělat jinak". A tuto chybu pak lze zpětně spatřovat ve všem - neměla jsem si vzít tak krátkou sukni, neměla jsem jít touhle ulicí, měla jsem si zavolat taxi, neměla jsem otvírat dveře. Toto uvažování je mylné, nebot' jakýkoli náš čin se dá zpětně vyložit jako chyba. Rozhodovat se s informacemi o tom, jak situace proběhla, je snadné. Když ale tato rozhodnutí činíme, tak máme informací mnohem méně a rozhodujeme se, jak v daném okamžiku nejlépe umíme.

Výrok je potenciálně traumatizující pro všechny oběti znásilnění. Ano, některé ženy se opravdu mohou chovat způsobem, který je rizikovější - jedná se bud' o podcenění rizik situace nebo o takzvané trauma reenactment (tedy často nevědomou snahu oběti zažít podobnou situaci znovu a s lepším koncem).

Na závěr se zeptejme slovy pana doktora: Ruku na srdce, kdo ve svém bytě v naší české společnosti v průběhu života neměl jednu nebo více opilých osob? Např́íklad na Silvestra? A opravdu jste čekali, že proto budete znásilněni?

Nakonec přidáváme ještě krátké, satirické video:

https://m.facebook.com/story.php?story_fbid=10157988214615787\&id=7519460786

Výroky, které zazněly v rozhovoru, jsou potenciálně ohrožující pro všechny oběti násilných sexuálních činů, přispívají ke kultuře násilí a degradují muže. V rozhovoru je patrná absence odbornosti, a to do zarážející míry.

\section{Údaje o autorech}

PhDr. Kateřina Bartošová, Ph.D. přednáší na katedře psychologie Pedagogické fakulty Masarykovy univerzity a pracuje s klienty v soukromé poradenské praxi.

Kontaktní údaje:

Adresa: Katedra psychologie Pedagogické fakulty MU, Poříčí 31, 60300 Brno

E-mail: 144972@mail.muni.cz

Mgr. Jana Cíglerová pracuje jako psycholožka v pedagogicko-psychologické poradně.

E-mail: janamafkova@gmail.com

Mgr. Hynek Cígler, Ph.D. přednáší na katedře psychologie a je výzkumným pracovníkem v Institutu výzkumu dětí, mládeže a rodiny, Fakulta sociálních studií Masarykovy univerzity. E-mail: hynek.cigler@mail.muni.cz

Bartošová, K., Cíglerová, J., Cígler, H. (2020). Vyjádření k rozhovoru Radima Uzla ze dne 8. 12. 2020. E-psychologie, 14(4), 68-71. https://doi.org/10.29364/epsy.386 